\title{
EVALUATION OF ANTIDIABETIC AND ANTIHYPERLIPIDEMIC EFFECT OF VERNONIA DIVERGENS IN STREPTOZOTOCIN-INDUCED DIABETIC RATS
}

\author{
LAXMIDHAR MAHARANA, MANOJ KUMAR SETHI*, RUDRA NARAYAN DASH, SNIGDHA PATTNAIK
}

Department of Pharmacology, School of Pharmaceutical Sciences, Siksha '0’ Anusandhan Deemed to be University, Bhubaneswar, Odisha, India. Email: manojsethi@soa.ac.in

Received: 31 January 2019, Revised and Accepted: 19 March 2019

\section{ABSTRACT}

Objective: The current investigation for antidiabetic activity of the plant Vernonia divergens (DC.) Edgew. has not been reported till date. However, to enlighten the folkloric claim of the plant, the study was carried out on various animal models such as albino mice, albino rabbits, Wistar rats, rabbits, hamsters, dogs, and monkeys.

Methods: The whole plant of V. divergens was studied on various animal models. Screening methods generally have been carried out on rodents and non-rodents, respectively. Various biochemical and hematological parameters such as serum glucose, plasma insulin, lipid profile and activities of liver enzymes, red blood cells, white blood cells, hemoglobin, and differential counts were measured to assess the antihyperglycemic and antihyperlipidemic activities as well as safety profile of the extract.

Results: Among all experimental extracts of $V$. divergens, it was found that the aqueous and methanolic extracts had maximum control of blood glucose in diabetic Wistar rats. While comparing with normoglycemic animals, it was observed that reduction of blood sugar level and increase in plasma insulin level are maximum with test extract. Among the study, the effects of the methanolic extract of $V$. divergens (MEVD) and aqueous extract of $V$. divergens (AEVD) were done through oral route in both the models, i.e., normoglycemic and hyperglycemic animal models. The safety profile was evaluated by toxicological evaluation and observed that, even at a higher dose level of $3000 \mathrm{mg} / \mathrm{kg}$ body weight, the MEVD and AEVD were safe and retain normal physiological and behavioral effect. The whole protein, whole cholesterol, aspartate aminotransferase, alanine aminotransferase, and alkaline phosphatase enzyme activity of streptozotocin-administered rats showed significantly higher than normal rats, and the test extract-treated rats significantly reduced the elevated levels.

Conclusion: It is concluded that the MEVD and AEVD (DC.) Edgew. might be beneficial in effectively reducing the blood glucose concentration and managing the various complications of diabetes. However, in comparison between both the extracts, the methanol extract was found to be significantly more potent than that of the A.E. in all aspects.

Keywords: Vernonia divergens (DC.) Edgew., Normoglycemic, Hyperglycemic, Wistar rats.

(C) 2019 The Authors. Published by Innovare Academic Sciences Pvt Ltd. This is an open access article under the CC BY license (http://creativecommons. org/licenses/by/4. 0/) DOI: http://dx.doi.org/10.22159/ajpcr.2019.v12i5.32301

\section{INTRODUCTION}

The term diabetes mellitus (DM) describes as a metabolic cum vascular syndrome of more than one etiology characterized by chronic hyperglycemia with resultant abnormalities in metabolism of protein fat and carbohydrate ensuing from impaired secretion and defected action of insulin or both. The outcomes of DM include long-term casualty, i.e., damage, dysfunction, and failure of several organs. DM may represent with attribute signs and symptoms such as polyphagia, polydipsia, polyurea, blurring of vision, and weight loss [1]. This is affecting nearly $25 \%$ of the population [2]. The prevalence of diabetes according to the World Health Organization projections is likely to increase by 35\% [3]. Currently, the incidence of diabetes is nearly 150 million globally, and by the year 2025 , this is likely to increase to 300 million or more $[3,4]$. While reviewing the statistical projection status of India, we can come across the fact that the incidence of diabetics is increasing and will rise from 15 million in 1995 to reach up to 57 million in the year 2025 which can make the country highest prevalent of diabetics worldwide [3]. Therefore, it is necessary to look for new solutions to manage this health problem. Many herbal products have been described for DM in ancient literature of Ayurveda in India [5]. The belief in traditionally used herbal drugs for curing various disease state is very strong in Nigeria and many other poor African countries [6,7].

India is one of the highest populated diabetogenic countries. In human population, DM remains one of the major contributors among all other diseases. Due to enhancing awareness now-a-days the concern of medicinal plant in health care system is increasing and interest in local plant remedies for treating of various disease is growing in many developed as well as developing countries. Vernonia divergens is commonly known as insulin plant having a potent effect against glucose reduction belonging to family Asteraceae which is used as an outstanding drug for DM described earlier [8]. Thus, the rationale of the present study was to ascertain the truth of the claim about antidiabetic activity on the plant $V$. divergens (DC.) Edgew. so that novel compound against the treatment of diabetes can be identified.

\section{METHODS}

\section{Collection and authentication of plant}

The plant $V$. divergens appears in the month of March and November. The whole plant was collected from Keonjhar district, a forest at Daitari, field No. 1, (Odisha). Before their use, they were carefully identified by Dr. Pratap Chandra Panda, Principal Scientist, Regional Plant Resource Centre, Bhubaneswar.

\section{Preparation of plant extracts}

The plants collected were dried at room temperature by the method of shade drying. The plants were spreaded over a polythene cover under fan. After drying, pulverizing was done with the help of mechanical grinder to get the powder form of plant material. The powder was then passed through a fine mesh sieve to get a fine powder. The powdered 
material (600 g) was extracted with different solvents separately of non-polar to polar, for example, petroleum ether (pet. ether), chloroform, methanol, and water by the help of Soxhlet apparatus. The liquid extracts were concentrated under vacuum to yield dry extracts and preserved in a desiccator until further experiments.

\section{Percentage yield of the extracts}

The percentage yield of the plant $V$. divergens was found to be $2.66 \%$, $1.66 \%, 14.66 \%$, and $12.66 \%$ with pet. ether, chloroform, methanol, and water, respectively. The percentage yield of the methanolic extract of $V$. divergens (MEVD) was found to be greater (14.66\%) than extracts with other solvents.

\section{Preparation of drug solution}

The semisolid extracts of $V$. divergens were dissolved in sufficient quantity of solvent (tween and normal saline), and the aqueous extracts (A.Es) were dissolved in normal saline for administration. Glibenclamide $5 \mathrm{mg} / \mathrm{kg}$ was dissolved in a sufficient quantity of normal saline and used in the treatment [9]. Streptozotocin $40 \mathrm{mg} / \mathrm{kg}$ was dissolved in the buffer solution and used to induce diabetes in rats [10].

\section{Selection of animals}

For both toxicological and antidiabetic assessments, adult Wistar albino rats of healthy status weighing about 150-200 g were selected after getting the Institutional Animal Ethics Committee approval (Approval No-10/15/SPS/IAEC/SOAU). The selected animals have been housed in acrylic cages in well-known environmental conditions (temperature: $20-25^{\circ} \mathrm{C}$ and relative humidity: $45-55 \%$ under $12 \mathrm{~h}$ light/dark cycle). To acclimate the laboratory condition, animals were fed with standard rodent diet for 1 week and water ad libitum [11].

\section{Induction of diabetes}

In the present study, a single dose of streptozotocin $40 \mathrm{mg} / \mathrm{kg}$ in normal saline was administered intraperitoneally [10]. After 1 week assessment of gradual development, diabetes was done. For the determination of blood glucose concentration, an experiment was performed on the $7^{\text {th }}$ day. The animals with blood glucose levels between 200 and $250 \mathrm{mg} / \mathrm{dl}$ were chosen for antidiabetic screening and they were considered as diabetic rats.

\section{Experimental procedure}

The study was carried out as mentioned below to check whether the MEVD is acting as an insulin secretagogue (stimulation of insulin secretion from the pancreatic $\beta$-cell and to check the utilization) activity as well as to check whether the MEVD possesses antidiabetic activity and hypoglycemic activity.

Overnight fasted animals were grouped in six groups of six animals each group.

\begin{tabular}{|c|c|c|c|c|}
\hline Group & $\begin{array}{l}\text { Animals } \\
\text { used }\end{array}$ & Sex & $\begin{array}{l}\text { Body } \\
\text { weight (g) }\end{array}$ & Treatment \\
\hline I & $\begin{array}{l}\text { Wistar } \\
\text { albino rats }\end{array}$ & Male & $150-200$ & $\begin{array}{l}\text { Served as control } \\
\text { (Normal saline). Once daily }\end{array}$ \\
\hline II & $\begin{array}{l}\text { Wistar } \\
\text { albino rats }\end{array}$ & Male & $150-200$ & $\begin{array}{l}\text { Served as standard } \\
\text { (Glibenclamide } 5 \mathrm{mg} / \mathrm{kg} \text { ). } \\
\text { Once daily }\end{array}$ \\
\hline III & $\begin{array}{l}\text { Wistar } \\
\text { albino rats }\end{array}$ & Male & $150-200$ & $\begin{array}{l}\text { Test drug I. Dose } 1 . \\
\text { once daily }\end{array}$ \\
\hline IV & $\begin{array}{l}\text { Wistar } \\
\text { albino rats }\end{array}$ & Male & $150-200$ & $\begin{array}{l}\text { Test drug I. Dose } 2 . \\
\text { once daily }\end{array}$ \\
\hline V & $\begin{array}{l}\text { Wistar } \\
\text { albino rats }\end{array}$ & Male & $150-200$ & $\begin{array}{l}\text { Test drug II. Dose } 1 . \\
\text { once daily }\end{array}$ \\
\hline VI & $\begin{array}{l}\text { Wistar } \\
\text { albino rats }\end{array}$ & Male & $150-200$ & $\begin{array}{l}\text { Test drug II. Dose } 2 . \\
\text { once daily }\end{array}$ \\
\hline
\end{tabular}

\section{Analytical procedure}

Blood sample was drawn into tubes at different time intervals. Serum was separated out by centrifugation and used in different estimations. Diabetes was induced by a single dose of Streptozotocin administration. Blood glucose level, which is elevated in association with hyperglycemia, was measured to assess whether the plant extract has antidiabetic/hypoglycemic effect. To estimate plasma insulin level insulin kit was used. Radioimmunoassay was performed by employing double antibody technique to get the final result [12]. A significant body weight reduction is associated with diabetes hence the body weight was recorded before, during and after the treatment. Acute toxic study was performed to find out toxic symptoms of the extract and gross behavioral changes were also noticed. Sub-acute toxicity study was performed to reveal the influence of the extract on biochemical, hematological and histopathological findings. Alanine aminotransferase (ALT), aspartate aminotransferase (AST), alkaline phosphatase (ALP) etc. were assayed in serum. Serum lipids like total cholesterol (TC), high density lipoprotein (HDL), Low density lipoprotein (LDL), Very LDL (VLDL) and triglyceride (TG) were estimated. Serum total protein and albumin were analyzed. Blood parameters like hemoglobin $(\mathrm{Hb})$, red blood cells (RBC), white blood cells (WBC) etc. counts were determined. Clotting time was also determined.

\section{Toxicity studies}

Acute toxicity studies

To rule out any toxicity of the extracts, acute oral toxicity test was performed on $12 \mathrm{~h}$ fasted healthy Wistar albino rats according to the principles of Organization for economic co-operation and development (OECD) (OECD guidelines 423) [13]. This study was performed with the major aim of therapeutic index establishment and also for the purpose of primary screening. Therapeutic index meant the ratio of pharmacologically effective dose to the lethal dose. A group of 10 mice have been fasting overnight was administered the A.E. of $V$. divergens (AEVD) once orally at 4 dose levels $(500,1000,2000,3000 \mathrm{mg} / \mathrm{kg})$. The initial observation of test drug treated mice was continuously recorded and then further reading was taken occasionally for $4 \mathrm{~h}$. Final recording of overnight mortality was done [14]. In the course of duration of study, spontaneous activity reduction and behaviors of the mice were attentively observed [15]

\section{Sub-acute toxicity studies}

The purpose of this study is to determine the maximum tolerated dose and daily dose for 3-4 weeks and to indicate the nature of toxic reaction of the drug. In present study, the influence of $V$. divergens extract on hematological parameters, a pathological change on 21 days dosing in streptozotocin induce diabetic rats were carried out. The diabetic rats were grouped into 6 groups of 6 animals each. Group I animals received solvent, Group II animals received standard drug, Group III (100 mg/kg body weight) and Group IV (200 mg/kg body weight) was received MEVD and Group V (100 mg/kg body weight) and Group VI (200 mg/kg body weight) was received AEVD once daily for 21 days. At the end of the experimental period the blood was collected, serum was separated and subjected to hematological and biochemical examination [14].

\section{Statistical analysis}

The values are represented as mean \pm standard error mean. The data obtained from various studies were subjected to one-way analysis of variance (ANOVA) [16]. Dunnett's t-test was also performed after ANOVA for establishing statistical significance.

\section{RESULTS}

In Table 1 Preliminary antidiabetic effect of various extracts of $V$. divergens on single dose treated diabetic rats induced by streptozotocin was shown. It revealed that pet. ether, chloroform, M.E. and A.E. registered $6.81 \%, 16.50 \%, 52.76 \%$ and $33.25 \%$ decrease in fasting blood glucose levels respectively at the dose level of $100 \mathrm{mg} / \mathrm{kg}$ in oral route at the end of $8 \mathrm{~h}$. However at the same time solvent control (distilled water) and pet. ether showed gradual increase in blood sugar level. The standard drug glibenclamide $5 \mathrm{mg} / \mathrm{kg}$ possess $72.84 \%$ decrease in blood glucose level at same duration. The A.E. significantly decreases the blood sugar level at the end of $4 \mathrm{~h}$ and $8 \mathrm{~h}$ in the level of $\mathrm{p}<0.01$, while the methanol 
extract (M.E.) showed significant decrease of blood sugar level starting from $2 \mathrm{~h}$ to the end of $8 \mathrm{~h}$ at the level of $\mathrm{p}<0.05$ to $\mathrm{p}<0.001$ with respect to solvent control. However the standard drug caused decrease of blood sugar level beginning from $1 \mathrm{~h}(\mathrm{p}<0.05)$ up to $8 \mathrm{~h}(\mathrm{p}<0.001)$ when compared with solvent.

Table 2 summarizes that the M.E. and A.E. at the dose level of $100 \mathrm{mg} / \mathrm{kg}$ and $200 \mathrm{mg} / \mathrm{kg}$ registered $19.33 \%$ and $30.72 \%$ and $14.54 \%$ and $25.08 \%$ reduction in glucose concentration of blood after $4 \mathrm{~h}$, respectively, while the standard drug glibenclamide $(5 \mathrm{mg} / \mathrm{kg}$ ) reduces blood glucose level up to $48.20 \%$ at the same time. At the end of $4 \mathrm{~h}$, the test extracts at two dose levels bear a significant $(\mathrm{p}<0.001)$ decrease of blood glucose compared to solvent control, while the standard drug holds the same significance $(\mathrm{p}<0.001)$ from the beginning of $2 \mathrm{~h}$

The data recorded in Table 3 showed that the M.E. and A.E. possess $25.79 \%$ and $36.81 \%$ and $19.44 \%$ and $33.31 \%$ decrease in blood glucose level at the dose level of $100 \mathrm{mg} / \mathrm{kg}$ and $200 \mathrm{mg} / \mathrm{kg}$, respectively, by oral route at the end of $8 \mathrm{~h}$, while the standard drug registered $48.45 \%$ reduction at the same time. However, the solvent control group showed a negligible reduction of blood glucose level at the end of $8 \mathrm{~h}$. The two extracts at the dose level of $100 \mathrm{mg} / \mathrm{kg}$ showed a significant decrease $(\mathrm{p}<0.01)$ at $8 \mathrm{~h}$, and at the same time, the dose level $200 \mathrm{mg} / \mathrm{kg}$ showed more significant $(\mathrm{p}<0.001)$ when compared to solvent control.

The result expressed in Table 4 revealed that the M.E. and A.E. in the dose level of $100 \mathrm{mg} / \mathrm{kg}$ and $200 \mathrm{mg} / \mathrm{kg}$ possess $48.54 \%$ and $55.00 \%$ and $34.10 \%$ and $50.09 \%$ reduction in the blood glucose level, respectively, at the end of $8 \mathrm{~h}$, while the standard drug registered $65.03 \%$ decrease in blood sugar level at the same time.

Table 5 shows the hypoglycemic effect of MEVD and AEVD on multidose treated normoglycemic rats. The purpose of the study is to establish the therapeutic validity of the test extracts in long-term use. The data showed that there was a decrease in blood sugar level to the extent of $25.56 \%$ and $34.14 \%$ in case of M.E. and $19.14 \%$ and $30.09 \%$ in case of A.E. at the dose level of $100 \mathrm{mg} / \mathrm{kg}$ and $200 \mathrm{mg} / \mathrm{kg}$, respectively, on the $21^{\text {st }}$ day of treatment.

The purpose of antidiabetic study is to confirm the antidiabetic effect of the test extracts on longer duration of treatment, and the data are shown in Table 6. The M.E. and A.Es are registered 50.68\% and 57.68\% and $40.55 \%$

Table 1: Preliminary antidiabetic effect of various extracts of Vernonia divergens on single dose treated streptozotocin-induced diabetic rats

\begin{tabular}{|c|c|c|c|c|c|c|}
\hline \multirow[t]{2}{*}{ Group and treatment } & \multicolumn{6}{|c|}{ Blood glucose levels (mg/dl) } \\
\hline & $\mathbf{0 ~ h}$ & $1 \mathrm{~h}$ & $2 \mathrm{~h}$ & $4 \mathrm{~h}$ & $8 \mathrm{~h}$ & $\%$ decrease at the end of $8 \mathrm{~h}$ \\
\hline Solvent (tween+water) & $251.2 \pm 11.5$ & $256.5 \pm 11.3$ & $274.3 \pm 9.3$ & $278.7 \pm 8.4$ & $282.3 \pm 8.4$ & - \\
\hline Standard glibenclamide $(5 \mathrm{mg} / \mathrm{kg})$ & $274.3 \pm 13.9$ & $201.2 \pm 11.6^{c}$ & $149.2 \pm 9.0^{c}$ & $101.7 \pm 9.6^{c}$ & $74.5 \pm 4.6^{c}$ & 72.84 \\
\hline Pet. ether extract $(100 \mathrm{mg} / \mathrm{kg})$ & $266.7 \pm 11.4$ & $275.3 \pm 11.9$ & $264.3 \pm 10.9$ & $254.7 \pm 9.2$ & $248.5 \pm 6.5^{c}$ & 6.81 \\
\hline Chloroform extract ( $100 \mathrm{mg} / \mathrm{kg})$ & $264.3 \pm 11.7$ & $253.2 \pm 9.8$ & $243.3 \pm 9.6$ & $224.5 \pm 8.9^{c}$ & $220.7 \pm 6.2^{c}$ & 16.50 \\
\hline Methanol extract $(100 \mathrm{mg} / \mathrm{kg})$ & $259.7 \pm 11.6$ & $241.2 \pm 9.6$ & $200.5 \pm 9.7^{c}$ & $148.3 \pm 10.9^{c}$ & $122.7 \pm 6.4^{c}$ & 52.76 \\
\hline Aqueous extract (100 mg/kg) & $271.7 \pm 13.8$ & $261.2 \pm 11.6$ & $223.5 \pm 10.3^{b}$ & $192.3 \pm 9.6^{c}$ & $181.3 \pm 7.9^{c}$ & 33.25 \\
\hline F values & 1.31 & $5.36^{* *}$ & $21.94 * *$ & $49.04 * *$ & $133.62^{* *}$ & \\
\hline
\end{tabular}

Values are explicated in the form of mean \pm SEM. To analyze the statistical significance, Dunnett's t-test and one-way ANOVA were executed. (F-value indicates statistical significance at ${ }^{*} \mathrm{p}<0.05,{ }^{*} \mathrm{p}<0.01$. t-value stands for statistical significance at ${ }^{\mathrm{a}} \mathrm{p}<0.05,{ }^{\mathrm{b}} \mathrm{p}<0.01$ and ${ }^{\mathrm{c}} \mathrm{p}<0.001$, respectively, when compared to Group I). SEM: Standard error mean, ANOVA: Analysis of variance, Pet. ether: Petroleum ether

Table 2: OGTT of MEVD and AEVD in single dose treated glucose-loaded hyperglycemic rats

\begin{tabular}{|c|c|c|c|c|c|c|}
\hline \multirow[t]{2}{*}{ Group and treatment } & \multicolumn{6}{|c|}{ Blood glucose levels (mg/dl) } \\
\hline & $60 \mathrm{~min}$ & $\mathbf{O} \mathbf{h}$ & $1 \mathrm{~h}$ & $2 \mathrm{~h}$ & $4 \mathrm{~h}$ & $\%$ decrease at the end of $4 \mathrm{~h}$ \\
\hline Solvent (tween+water) & $104.2 \pm 4.6$ & $107.5 \pm 4.1$ & $123.3 \pm 2.4$ & $136.5 \pm 2.0$ & $102.3 \pm 2.6$ & - \\
\hline Standard glibenclamide (5 mg/kg) & $104.5 \pm 4.4$ & $90.2 \pm 3.8$ & $78.7 \pm 2.7^{c}$ & $66.5 \pm 2.9^{c}$ & $54.2 \pm 2.7^{c}$ & 48.20 \\
\hline MEVD (100 mg/kg) & $104.3 \pm 4.5$ & $102.2 \pm 2.4$ & $92.5 \pm 2.7^{c}$ & $88.7 \pm 2.9^{c}$ & $84.16 \pm 2.1^{c}$ & 19.33 \\
\hline MEVD (200 mg/kg) & $104.7 \pm 4.3$ & $95.3 \pm 2.1^{\mathrm{b}}$ & $84.2 \pm 2.2^{c}$ & $78.2 \pm 2.4^{c}$ & $72.5 \pm 2.4^{c}$ & 30.72 \\
\hline AEVD (100 mg/kg) & $105.5 \pm 4.0$ & $104.5 \pm 3.9$ & $98.5 \pm 2.8^{\mathrm{c}}$ & $93.3 \pm 2.8^{c}$ & $90.2 \pm 2.8^{\mathrm{b}}$ & 14.54 \\
\hline AEVD (200 mg/kg) & $105.7 \pm 3.9$ & $99.3 \pm 2.8$ & $90.7 \pm 2.5^{c}$ & $85.2 \pm 2.2^{c}$ & $79.3 \pm 1.8^{c}$ & 25.08 \\
\hline F value & & $3.63^{*}$ & $37.14^{* *}$ & $89.25^{* *}$ & $45.30^{* *}$ & \\
\hline
\end{tabular}

Values are explicated in the form of mean \pm SEM. To analyze the statistical significance, Dunnett's t-test and one-way ANOVA were executed. (F-value indicates statistical significance at ${ }^{*} \mathrm{p}<0.05,{ }^{* *} \mathrm{p}<0.01$. t-value stands for statistical significance at ${ }^{\mathrm{a}} \mathrm{p}<0.05,{ }^{\mathrm{b}} \mathrm{p}<0.01$, and ${ }^{\mathrm{c}} \mathrm{p}<0.001$, respectively, when compared to Group I). OGTT: Oral glucose tolerance test, SEM: Standard error mean, ANOVA: Analysis of variance, MEVD: Methanolic extract of Vernonia divergens, AEVD: Aqueous extract of Vernonia divergens

Table 3: Hypoglycemic effect of MEVD and AEVD on single dose treated normoglycemic rats

\begin{tabular}{|c|c|c|c|c|c|c|}
\hline \multirow[t]{2}{*}{ Group and treatment } & \multicolumn{6}{|c|}{ Blood glucose levels (mg/dl) } \\
\hline & $\mathbf{O} \mathbf{h}$ & $1 \mathrm{~h}$ & $2 \mathrm{~h}$ & $4 \mathrm{~h}$ & $8 \mathrm{~h}$ & $\%$ decrease at the end of $8 \mathrm{~h}$ \\
\hline Solvent (tween+water) & $103.3 \pm 2.4$ & $103.7 \pm 2.0$ & $104.3 \pm 2.2$ & $106.3 \pm 2.4$ & $105.2 \pm 1.8$ & - \\
\hline Standard glibenclamide $(5 \mathrm{mg} / \mathrm{kg})$ & $102.2 \pm 2.9$ & $90.5 \pm 3.1^{\mathrm{b}}$ & $81.7 \pm 2.5^{c}$ & $74.3 \pm 1.2^{\mathrm{c}}$ & $52.7 \pm 1.3^{c}$ & 48.45 \\
\hline MEVD $(100 \mathrm{mg} / \mathrm{kg})$ & $104.7 \pm 2.8$ & $104.5 \pm 2.2$ & $97.2 \pm 1.9^{a}$ & $94.2 \pm 1.9^{c}$ & $77.7 \pm 2.7^{c}$ & 25.79 \\
\hline MEVD (200 mg/kg) & $102.3 \pm 2.4$ & $102.5 \pm 2.4$ & $95.5 \pm 1.4^{\mathrm{b}}$ & $85.3 \pm 1.5^{c}$ & $64.7 \pm 1.5^{c}$ & 36.81 \\
\hline AEVD (100 mg/kg) & $103.7 \pm 2.7$ & $103.2 \pm 2.5$ & $99.5 \pm 1.5^{a}$ & $96.2 \pm 1.3^{\mathrm{b}}$ & $83.5 \pm 4.5^{c}$ & 19.44 \\
\hline AEVD (200 mg/kg) & $103.7 \pm 1.2$ & $103.5 \pm 1.2$ & $96.7 \pm 1.4^{\mathrm{a}}$ & $90.2 \pm 1.6^{c}$ & $70.2 \pm 2.1^{c}$ & 32.31 \\
\hline F value & 1.05 & $5.31^{* *}$ & $16.56^{* *}$ & $39.97 * *$ & $54.81^{* *}$ & \\
\hline
\end{tabular}

Values are explicated in the form of mean \pm SEM. To analyze the statistical significance, Dunnett's t-test and one-way ANOVA were executed. (F-value indicates statistical significance at ${ }^{*} \mathrm{p}<0.05,{ }^{* *} \mathrm{p}<0.01$. t-value stands for statistical significance at ${ }^{\mathrm{a}} \mathrm{p}<0.05,{ }^{\mathrm{b}} \mathrm{p}<0.01$, and ${ }^{\mathrm{c}} \mathrm{p}<0.001$, respectively, when compared to Group I). SEM: Standard error mean, ANOVA: Analysis of variance, MEVD: Methanolic extract of Vernonia divergens, AEVD: Aqueous extract of Vernonia divergens 
and $52.59 \%$ of decrease of blood glucose level at the tested dose level of $100 \mathrm{mg} / \mathrm{kg}$ and $200 \mathrm{mg} / \mathrm{kg}$, respectively, on the $21^{\text {st }}$ day of treatment, while the standard drug showed $60.81 \%$ reduction on the same day.

Plasma insulin levels significantly $(\mathrm{p}<0.001)$ increased in case of both M.E. and A.Es at both $100 \mathrm{mg} / \mathrm{kg}$ and $200 \mathrm{mg} / \mathrm{kg}$ dose level. Both extracts at both the dose level indicated a rise in insulin concentration of
133.43 and 173.37 and 126.51 and $156.16 \mu \mathrm{U} / \mathrm{ml}$, respectively, on $14^{\text {th }}$ day, while standard drug glibenclamide showed highest concentration of plasma insulin, i.e., $181.94 \mu \mathrm{U} / \mathrm{ml}$ at the end of $14^{\text {th }}$ day and the data are depicted in Table 7.

The content of Table 8 indicated that there was a decrease in percentage loss of body weight when measured on $3^{\text {rd }}, 7^{\text {th }}, 14^{\text {th }}$, and $21^{\text {st }}$

Table 4: Antidiabetic activity of MEVD and AEVD in single dose treated streptozotocin-induced diabetic rats

\begin{tabular}{|c|c|c|c|c|c|c|}
\hline \multirow[t]{2}{*}{ Group and treatment } & \multicolumn{6}{|c|}{ Blood glucose levels (mg/dl) } \\
\hline & $\mathbf{O} \mathbf{h}$ & $1 \mathrm{~h}$ & $2 \mathrm{~h}$ & $4 \mathrm{~h}$ & 8 h & $\%$ decrease at the end of $8 \mathrm{~h}$ \\
\hline Solvent (tween+water) & $252.5 \pm 10.6$ & $258.7 \pm 10.2$ & $272.7 \pm 9.4$ & $288.5 \pm 8.9$ & $297.7 \pm 7.1$ & - \\
\hline MEVD (100 mg/kg) & $263.3 \pm 9.7$ & $254.7 \pm 9.5$ & $226.3 \pm 8.8^{b}$ & $171.2 \pm 5.9^{c}$ & $135.5 \pm 4.4^{c}$ & 48.54 \\
\hline MEVD (200 mg/kg) & $261.2 \pm 9.5$ & $245.6 \pm 10.1$ & $211.7 \pm 9.0^{c}$ & $148.3 \pm 6.1^{c}$ & $117.5 \pm 6.4^{c}$ & 55.00 \\
\hline AEVD (100 mg/kg) & $273.7 \pm 10.2$ & $266.2 \pm 10.3$ & $246.5 \pm 8.6$ & $200.6 \pm 5.5^{c}$ & $180.3 \pm 5.3^{c}$ & 34.10 \\
\hline AEVD (200 mg/kg) & $271.5 \pm 9.7$ & $258.7 \pm 9.6$ & $227.3 \pm 8.8^{b}$ & $168.7 \pm 5.9^{c}$ & $135.5 \pm 4.1^{c}$ & 50.09 \\
\hline F value & 0.38 & 0.46 & $6.37 * *$ & $72.31^{* *}$ & $171.09^{* *}$ & \\
\hline
\end{tabular}

Values are explicated in the form of mean \pm SEM. To analyze the statistical significance, Dunnett's t-test and one-way ANOVA were executed. (F-value indicates statistical significance at ${ }^{*} \mathrm{p}<0.05,{ }^{* *} \mathrm{p}<0.01$. t-value stands for statistical significance at ${ }^{\mathrm{a}} \mathrm{p}<0.05,{ }^{\mathrm{b}} \mathrm{p}<0.01$, and ${ }^{\mathrm{c}} \mathrm{p}<0.001$, respectively, when compared to Group I). SEM: Standard error mean, ANOVA: Analysis of variance, MEVD: Methanolic extract of Vernonia divergens, AEVD: Aqueous extract of Vernonia divergens

Table 5: Hypoglycemic effect of MEVD and AEVD on multidose treated normoglycemic rats

\begin{tabular}{llllll}
\hline \multirow{2}{*}{ Group and treatment } & \multicolumn{2}{l}{ Blood glucose levels (mg/dl) } & & \\
\cline { 2 - 5 } & Day 0 & Day 7 & Day 14 & Day 21 & \% decrease at the end of day 21 \\
\hline Solvent (tween+water) & $104.2 \pm 2.2$ & $104.8 \pm 2.4$ & $104.7 \pm 2.1$ & $105.5 \pm 2.6$ & - \\
Standard glibenclamide (5 mg/kg) & $106.2 \pm 2.9$ & $86.16 \pm 2.8^{\mathrm{c}}$ & $68.5 \pm 2.7^{\mathrm{c}}$ & $52.3 \pm 2.0^{\mathrm{c}}$ & 50.70 \\
MEVD (100 mg/kg) & $104.3 \pm 2.5$ & $101.5 \pm 2.2$ & $93.3 \pm 2.4^{\mathrm{b}}$ & $77.7^{\mathrm{b}} \pm 2.6^{\mathrm{c}}$ & 25.56 \\
MEVD (200 mg/kg) & $104.5 \pm 2.4$ & $98.2 \pm 2.5$ & $84.7 \pm 2.9^{\mathrm{c}}$ & $68.5 \pm 2.0^{\mathrm{c}}$ & 34.34 \\
AEVD (100 mg/kg) & $105.3 \pm 2.5$ & $103.5 \pm 2.2$ & $97.5 \pm 2.0$ & $85.16 \pm 2.1^{\mathrm{c}}$ & 19.14 \\
AEVD (200 mg/kg) & $104.7 \pm 2.3$ & $100.3 \pm 2.1$ & $89.7 \pm 1.9$ & $73.2 \pm 2.2^{\mathrm{c}}$ & 30.09 \\
F value & & $8.09^{* *}$ & $27.59^{* *}$ & $60.61^{* *}$ \\
\hline
\end{tabular}

Values are explicated in the form of mean \pm SEM. To analyze the statistical significance, Dunnett's t-test and one-way ANOVA were executed. (F-value indicates statistical significance at ${ }^{*} \mathrm{p}<0.05,{ }^{* *} \mathrm{p}<0.01$. t-value stands for statistical significance at ${ }^{\mathrm{a}} \mathrm{p}<0.05,{ }^{\mathrm{b}} \mathrm{p}<0.01$, and ${ }^{\mathrm{c}} \mathrm{p}<0.001$, respectively, when compared to Group I). SEM: Standard error mean, ANOVA: Analysis of variance, MEVD: Methanolic extract of Vernonia divergens, AEVD: Aqueous extract of Vernonia divergens

Table 6: Antidiabetic activity of MEVD and AEVD on multidose treated streptozotocin-induced diabetic rats

\begin{tabular}{|c|c|c|c|c|c|c|}
\hline \multirow[t]{2}{*}{ Group and treatment } & \multicolumn{6}{|c|}{ Blood glucose levels (mg/dl) } \\
\hline & Day 0 & Day 3 & Day 7 & Day 14 & Day 21 & $\%$ decrease at the end of day 21 \\
\hline Solvent (tween+water) & $275.3 \pm 4.2$ & $265.5 \pm 4.1$ & $253.7 \pm 4.1$ & $238.5 \pm 6.1$ & $238.5 \pm 6.1$ & - \\
\hline MEVD (100 mg/kg) & $279.2 \pm 4.2$ & $263.3 \pm 4.0$ & $233.2 \pm 5.4^{\mathrm{a}}$ & $186.2 \pm 4.2^{\mathrm{c}}$ & $137.7 \pm 4.2^{\mathrm{c}}$ & 50.68 \\
\hline MEVD (200 mg/kg) & $280.5 \pm 3.8$ & $261.7 \pm 4.8$ & $226.2 \pm 4.7^{b}$ & $173.2 \pm 3.1^{\mathrm{c}}$ & $118.7 \pm 4.5^{c}$ & 57.69 \\
\hline AEVD (100 mg/kg) & $278.7 \pm 4.7$ & $272.2 \pm 3.3$ & $250.7 \pm 5.1$ & $210.2 \pm 4.7^{\mathrm{a}}$ & $165.7 \pm 4.2^{c}$ & 40.55 \\
\hline AEVD (200 mg/kg) & $279.5 \pm 4.3$ & $267.7 \pm 4.3$ & $230.7 \pm 5.1^{b}$ & $181.5 \pm 4.7^{c}$ & $132.5 \pm 4.2^{c}$ & 52.59 \\
\hline F value & 0.36 & $15.63^{* * *}$ & $28.44^{* * *}$ & $40.13^{* * *}$ & $108.00^{* * *}$ & \\
\hline
\end{tabular}

Values are explicated in the form of mean \pm SEM. To analyze the statistical significance, Dunnett's t-test and one-way ANOVA were executed. (F-Value indicates statistical significance at ${ }^{*} \mathrm{p}<0.05,{ }^{* *} \mathrm{p}<0.01$. t-value stands for statistical significance at ${ }^{\mathrm{a}} \mathrm{p}<0.05,{ }^{\mathrm{b}} \mathrm{p}<0.01$, and ${ }^{\mathrm{c}} \mathrm{p}<0.001$, respectively, when compared to Group I). SEM: Standard error mean, ANOVA: Analysis of variance, MEVD: Methanolic extract of Vernonia divergens, AEVD: Aqueous extract of Vernonia divergens

Table 7: Effect of MEVD and AEVD on plasma insulin levels in streptozotocin-induced diabetic rats

\begin{tabular}{|c|c|c|c|c|}
\hline \multirow[t]{2}{*}{ Group and treatment } & \multicolumn{4}{|c|}{ Plasma insulin level $(\mu \mathrm{U} / \mathrm{ml})$} \\
\hline & Day 0 & Day 7 & Day 14 & Day 21 \\
\hline Solvent (tween+water) & $22.66 \pm 3.75$ & $21.28 \pm 2.80$ & $26.87 \pm 3.54$ & $23.58 \pm 2.79$ \\
\hline Standard glibenclamide $(5 \mathrm{mg} / \mathrm{kg})$ & $33.84 \pm 3.67^{c}$ & $169.95 \pm 11.61^{\mathrm{c}}$ & $181.94 \pm 9.58^{c}$ & $113.86 \pm 7.59^{c}$ \\
\hline MEVD $(100 \mathrm{mg} / \mathrm{kg})$ & $23.56 \pm 2.87^{b}$ & $94.38 \pm 9.58^{c}$ & $133.43 \pm 11.49^{c}$ & $115.29 \pm 9.13^{c}$ \\
\hline MEVD (200 mg/kg) & $32.89 \pm 3.51^{\mathrm{c}}$ & $154.18 \pm 11.83^{c}$ & $173.37 \pm 10.53^{c}$ & $121.93 \pm 8.19^{c}$ \\
\hline AEVD (100 mg/kg) & $24.36 \pm 3.73^{\mathrm{b}}$ & $89.66 \pm 7.56^{c}$ & $126.5 \pm 9.14^{c}$ & $113.58 \pm 9.41^{\mathrm{c}}$ \\
\hline AEVD (200 mg/kg) & $32.66 \pm 2.65^{c}$ & $145.51 \pm 12.53^{c}$ & $156.16 \pm 10.25^{c}$ & $117.84 \pm 6.23^{c}$ \\
\hline F value & $3.61^{*}$ & $44.34 * *$ & $73.21^{* *}$ & $87.32 * *$ \\
\hline
\end{tabular}

Values are explicated in the form of mean \pm SEM. To analyze the statistical significance, Dunnett's t-test and one-way ANOVA were executed. (F-value indicates statistical significance at ${ }^{*} \mathrm{p}<0.05,{ }^{* *} \mathrm{p}<0.01$. t-value stands for statistical significance at ${ }^{\mathrm{a}} \mathrm{p}<0.05,{ }^{\mathrm{b}} \mathrm{p}<0.01$, and ${ }^{\mathrm{c}} \mathrm{p}<0.001$, respectively, when compared to Group I). SEM: Standard error mean, ANOVA: Analysis of variance, MEVD: Methanolic extract of Vernonia divergens, AEVD: Aqueous extract of Vernonia divergens 
days of treatment in both tested dose levels. The M.E. at $100 \mathrm{mg} / \mathrm{kg}$ possesses $6.72 \%$ loss of body weight on $21^{\text {st }}$ day, while on the $3^{\text {rd }}$ day, the percentage loss of body weight registered $12 \%$. Similarly at a dose level of $200 \mathrm{mg} / \mathrm{kg}$ on $21^{\text {st }}$ day measured $5.55 \%$ and on $3^{\text {rd }}$ day $10 \%$ loss of body weight. The A.E. at $100 \mathrm{mg} / \mathrm{kg}$ possesses $7.42 \%$ loss of body weight on $21^{\text {st }}$ day, while on the $3^{\text {rd }}$ day, the percentage loss of body weight registered $11 \%$. Similarly at dose level of $200 \mathrm{mg} / \mathrm{kg}$ on $21^{\text {st }}$ day measured $5.8 \%$ and on $3^{\text {rd }}$ day $10 \%$ loss of body weight.

The data presented in Table 9 demonstrated that the glycogen content of the liver and kidney of DM animals treated with M.E. and A.Es of leaves of $V$. divergens and standard drug was significantly increased

Table 8: Percentage loss of body weight in MEVD and AEVD in streptozotocin-induced diabetic rats

\begin{tabular}{lllll}
\hline \multirow{2}{*}{ Group and treatment } & \multicolumn{4}{c}{ Percentage loss of body weights } \\
\cline { 2 - 5 } & Day 3 & Day 7 & Day 14 & Day 21 \\
\hline Solvent (tween+water) & 10 & 16 & 18.66 & 25.33 \\
Standard glibenclamide & 8 & 6.66 & 6.66 & 3.33 \\
(5 mg/kg) & & & & \\
MEVD (100 mg/kg) & 12 & 10.11 & 8.0 & 6.72 \\
MEVD (200 mg/kg) & 10 & 8.23 & 6.38 & 5.55 \\
AEVD (100 mg/kg) & 11 & 10.15 & 9.0 & 7.42 \\
AEVD (200 mg/kg) & 10 & 8.15 & 6.66 & 5.8 \\
\hline
\end{tabular}

The values indicating the percentage loss in body weights are calculated from the mean body weights of animals $(n=6)$, in the respective groups on the respective days. MEVD: Methanolic extract of Vernonia divergens, AEVD: Aqueous extract of Vernonia divergens

Table 9: Effect of MEVD and AEVD on the glycogen concentration in the liver and kidney

\begin{tabular}{lll}
\hline Group and treatment & $\begin{array}{l}\text { Liver glycogen } \\
\text { mg/g tissue }\end{array}$ & $\begin{array}{l}\text { Kidney glycogen } \\
\text { mg/g tissue }\end{array}$ \\
\hline Solvent (tween+water) & $19.16 \pm 2.21$ & $11.48 \pm 1.50$ \\
Standard glibenclamide & $33.66 \pm 2.76^{* *}$ & $17.50 \pm 1.80^{*}$ \\
(5 mg/kg) & & \\
Normal & $35.67 \pm 2.70$ & $19.40 \pm 1.40$ \\
MEVD $(100 \mathrm{mg} / \mathrm{kg})$ & $28.46 \pm 1.19^{*}$ & $13.60 \pm 2.20$ \\
MEVD $(200 \mathrm{mg} / \mathrm{kg})$ & $31.80 \pm 4.40^{* *}$ & $15.67 \pm 1.67$ \\
AEVD $(100 \mathrm{mg} / \mathrm{kg})$ & $27.66 \pm 2.65^{*}$ & $12.60 \pm 2.06$ \\
AEVD $(200 \mathrm{mg} / \mathrm{kg})$ & $30.16 \pm 2.72^{* *}$ & $14.5 \pm 1.19$ \\
F value & $5.09^{\mathrm{b}}$ & $3.10^{\mathrm{a}}$ \\
\hline
\end{tabular}

Values are explicated in the form of mean \pm SEM. To analyze the statistical significance Dunnett's t-test and one-way ANOVA were executed. (F-Value indicates statistical significance at $* \mathrm{p}<0.05,{ }^{* *} \mathrm{p}<0.01$. t-value stands for statistical significance at ${ }^{\mathrm{a}} \mathrm{p}<0.05,{ }^{\mathrm{b}} \mathrm{p}<0.01$, and ${ }^{\mathrm{c}} \mathrm{p}<0.001$, respectively, when compared to Group I). SEM: Standard error mean, ANOVA: Analysis of variance, MEVD: Methanolic extract of Vernonia divergens, AEVD: Aqueous extract of Vernonia divergens when compared with solvent control after the completion of 21 days of drug exposure, even the test extracts and standard drug approach the content of glycogen toward normal level.

The data observed in Table 10 present a significant $(\mathrm{p}<0.01)$ reduction of TC in serum in the groups treated with test extraction and standard drug when compared with solvent control. The extent of reduction in both the close level of test extracts was dose dependent. In case of TGs, there was a significant reduction with both test extract and standard drug when compared with solvent control on the $21^{\text {st }}$ day of treatment. The value of HDL in case of test extract at tested dose levels and standard drug showed significant increase than that of solvent control group, while the LDL and VLDL levels significantly $(\mathrm{p}<0.001)$ decrease in all drug-treated groups when compared with solvent control.

The hematological parameters exhibited in Table 11 show that the animals treated with standard drug glibenclamide and test extracts in the tested dose levels bear normal in RBC count and $\mathrm{Hb}$, whereas the clotting time slightly elevated. However, the diabetic rats treated with solvent showed a decrease value of $\mathrm{RBC}, \mathrm{WBC}$, and $\mathrm{Hb}$. The neutrophil count appears to nearly equal with that of normal value. The other hematological parameters such as eosinophil, lymphocyte, and monocytes in case of the standard drug and test extract-treated animals did not show any alteration.

From Table 12, it was observed that AST and ALT enzyme activity of streptozotocin-induced diabetic rats was significantly higher than normal rats. The test extracts and treated rats at tested dose had reduced enzyme activity when compared with diabetic rats. The total protein and albumin content of serum was significantly lowered in diabetic rats when compared with solvent control, but in the drugtreated diabetic animals, it returned to nearly normal.

\section{DISCUSSION}

Diabetes is a chronic disease that occurs when either insulin deficiency or resistance or both exists. The hyperglycemic condition causes increased glycosylation leading to various complications such as neuropathy, retinopathy, nephropathy, and cardiomyopathy [17]. The present study was carried out to investigate and validate the antidiabetic activity of the plant $V$. divergens (DC.) Edgew. The blood glucose lowering property of MEVD and AEVD is comparable with the standard drug glibenclamide ( $5 \mathrm{mg} / \mathrm{kg}$ body weight). Among the tested extract, the M.E. and A.E. at the dose level of $100 \mathrm{mg} / \mathrm{kg}$ possess a marked reduction in blood glucose level through oral route. Therefore, the M.E. and A.E. were selected for the evaluation of hypoglycemic and/or antidiabetic activity. It is observed that the MEVD and AEVD effectively control the glucose concentration of blood in normoglycemic as well as hyperglycemic rats in single unit dose treated model. The background mechanism of such effect might be due to a decrease in the initial absorption rate when glucose and plant fiber given together orally [18]. Hence, it may be presumed that the glucose lowering effect

Table 10: Effect of MEVD and AEVD on lipid profile in subacute toxicity

\begin{tabular}{|c|c|c|c|c|c|}
\hline \multirow[t]{2}{*}{ Group and treatment } & \multicolumn{5}{|l|}{ Lipid profile } \\
\hline & TC (mg/dl) & TG (mg/dl) & HDL (mg/dl) & LDL (mg/dl) & VLDL (mg/dl) \\
\hline Solvent (tween+water) & $226.8 \pm 5.4$ & $180.0 \pm 6.7$ & $34.2 \pm 4.1$ & $162.8 \pm 6.3$ & $42.7 \pm 3.0$ \\
\hline Standard glibenclamide (5 mg/kg) & $160.3 \pm 4.7^{c}$ & $101.8 \pm 3.1^{c}$ & $46.7 \pm 3.3^{\mathrm{a}}$ & $84.7 \pm 5.3^{c}$ & $23.8 \pm 2.6^{c}$ \\
\hline Normal & $137.8 \pm 4.1$ & $87.2 \pm 1.7$ & $50.7 \pm 3.3$ & $65.2 \pm 4.7$ & $17.2 \pm 3.0$ \\
\hline MEVD (100 mg/kg) & $194.2 \pm 4.1$ & $134.8 \pm 5.0^{\mathrm{b}}$ & $38.2 \pm 4.6$ & $134.7 \pm 5.1$ & $31.7 \pm 2.4^{\mathrm{a}}$ \\
\hline MEVD (200 mg/kg) & $185.5 \pm 5.5^{\mathrm{b}}$ & $114.3 \pm 4.6^{c}$ & $40.2 \pm 3.5$ & $114.8 \pm 4.1^{\mathrm{b}}$ & $28.3 \pm 2.1^{b}$ \\
\hline AEVD (100 mg/kg) & $205.2 \pm 5.0$ & $145.5 \pm 5.1$ & $36.5 \pm 5.4$ & $148.2 \pm 5.4$ & $35.8 \pm 3.1$ \\
\hline AEVD (200 mg/kg) & $191.7 \pm 4.1$ & $124.3 \pm 5.0$ & $39.6 \pm 4.1$ & $129.7 \pm 4.7$ & $30.2 \pm 3.0$ \\
\hline F value & $56.27^{* *}$ & $54.53^{* *}$ & $2.76^{*}$ & $57.79 * *$ & $13.51^{* *}$ \\
\hline
\end{tabular}

Values are explicated in the form of mean \pm SEM. To analyze the statistical significance, Dunnett's t-test and one-way ANOVA were executed. (F-value indicates statistical significance at ${ }^{*} \mathrm{p}<0.05,{ }^{* *} \mathrm{p}<0.01$. t-value stands for statistical significance at ${ }^{\mathrm{a}} \mathrm{p}<0.05,{ }^{\mathrm{b}} \mathrm{p}<0.01$, and ${ }^{\mathrm{c}} \mathrm{p}<0.001$, respectively, when compared to Group I). SEM: Standard error mean, ANOVA: Analysis of variance, MEVD: Methanolic extract of Vernonia divergens, AEVD: Aqueous extract of Vernonia divergens, TC: Total cholesterol, TG: Triglyceride, HDL: High-density lipoprotein, LDL: Low-density lipoprotein, VLDL: Very low-density lipoprotein 
Table 11: Effect of MEVD and AEVD on hematological parameters in subacute toxicity

\begin{tabular}{|c|c|c|c|c|c|c|c|c|}
\hline Group and treatment & $\begin{array}{l}\text { RBC } \\
\text { (millions/ml) }\end{array}$ & $\begin{array}{l}\text { WBC } \\
\text { (millions/ml) }\end{array}$ & $\begin{array}{l}\mathrm{Hb} \\
(\mathrm{g} / \mathrm{dl})\end{array}$ & $\begin{array}{l}\text { Clotting time } \\
\text { (min) }\end{array}$ & $\begin{array}{l}\text { Neutrophil } \\
(\%)\end{array}$ & $\begin{array}{l}\text { Eosinophil } \\
(\%)\end{array}$ & $\begin{array}{l}\text { Lymphocyte } \\
(\%)\end{array}$ & $\begin{array}{l}\text { Monocyte } \\
(\%)\end{array}$ \\
\hline Solvent (tween+water) & $2.7 \pm 0.4$ & $7.9 \pm 0.9$ & $7.3 \pm 1.5$ & $1.4 \pm 0.01$ & $21.2 \pm 3.7$ & $4.7 \pm 0.7$ & $72.7 \pm 4.5$ & $4.5 \pm 0.7$ \\
\hline $\begin{array}{l}\text { Standard glibenclamide } \\
(5 \mathrm{mg} / \mathrm{kg})\end{array}$ & $4.9 \pm 0.6^{\mathrm{a}}$ & $6.9 \pm 1.1$ & $10.6 \pm 1.2$ & $1.1 \pm 0.08$ & $27.8 \pm 2.3$ & $1.9 \pm 0.5^{c}$ & $69.8 \pm 3.3$ & $2.7 \pm 0.7$ \\
\hline Normal & $5.2 \pm 0.6$ & $7.2 \pm 1.2$ & $11.8 \pm 1.4$ & $1.1 \pm 0.07$ & $32.7 \pm 1.5$ & $1.5 \pm 0.07$ & $68.7 \pm 3.3$ & $1.8 \pm 0.2$ \\
\hline MEVD (100 mg/kg) & $3.7 \pm 0.8$ & $6.2 \pm 0.4$ & $8.3 \pm 1.5$ & $1.4 \pm 0.07$ & $24.3 \pm 2.1$ & $2.5 \pm 0.3^{b}$ & $71.4 \pm 4.1$ & $3.3 \pm 0.9$ \\
\hline MEVD (200 mg/kg) & $4.6 \pm 0.7$ & $6.6 \pm 0.7$ & $8.8 \pm 1.2$ & $1.3 \pm 0.07$ & $26.2 \pm 1.6$ & $2.1 \pm 0.4^{\mathrm{b}}$ & $70.3 \pm 3.9$ & $3.1 \pm 0.3$ \\
\hline AEVD (200 mg/kg) & $4.1 \pm 0.5$ & $6.4 \pm 0.9$ & $8.5 \pm 1.2$ & $1.3 \pm 0.7$ & $25.2 \pm 1.2$ & $2.3 \pm 0.2$ & $70.8 \pm 3.3$ & $3.2 \pm 0.5$ \\
\hline F value & $2.8^{*}$ & 1.05 & 2.02 & $3.88^{*}$ & $3.2^{*}$ & $8.50 * *$ & 0.95 & 2.17 \\
\hline
\end{tabular}

Values are explicated in the form of mean \pm SEM. To analyze the statistical significance, Dunnett's t-test and one-way ANOVA was executed. (F-value indicates statistical significance at ${ }^{*} \mathrm{p}<0.05,{ }^{* *} \mathrm{p}<0.01$. t-value stands for statistical significance at ${ }^{\mathrm{a}} \mathrm{p}<0.05,{ }^{\mathrm{b}} \mathrm{p}<0.01$, and ${ }^{\mathrm{c}} \mathrm{p}<0.001$, respectively, when compared to Group I). SEM: Standard error mean, ANOVA: Analysis of variance, MEVD: Methanolic extract of Vernonia divergens, AEVD: Aqueous extract of Vernonia divergens, RBC: Red blood cells, WBC: White blood cells

Table 12: Effect of MEVD and AEVD on biochemical parameters in subacute toxicity

\begin{tabular}{|c|c|c|c|c|c|}
\hline Group and treatment & $\operatorname{AST}(\mu \mathrm{l})$ & ALT $(\mu l)$ & $\operatorname{ALP}(\mu \mathrm{l})$ & Albumin (g/dl) & Total Protein (g/dl) \\
\hline Solvent (Tween+water) & $36.16 \pm 3.8$ & $48.67 \pm 4.1$ & $290.50 \pm 4.5$ & $5.82 \pm 0.8$ & $4.76 \pm 0.8$ \\
\hline Standard glibenclamide $(5 \mathrm{mg} / \mathrm{kg}$ ) & $25.17 \pm 3.2^{\mathrm{a}}$ & $30.34 \pm 2.3^{b}$ & $270.84 \pm 4.9^{a}$ & $4.20 \pm 0.8$ & $6.26 \pm 1.0$ \\
\hline Normal & $22.84 \pm 3.9$ & $28.34 \pm 3.4$ & $262.17 \pm 6.1$ & $3.40 \pm 0.4$ & $8.08 \pm 0.5$ \\
\hline MEVD (100 mg/kg) & $35.84 \pm 3.9$ & $38.84 \pm 3.0^{\mathrm{a}}$ & $282.17 \pm 5.0$ & $5.16 \pm 0.8$ & $5.18 \pm 0.8$ \\
\hline MEVD (200 mg/kg) & $30.67 \pm 3.1$ & $34.67 \pm 2.2^{\mathrm{b}}$ & $276.16 \pm 4.5^{\mathrm{a}}$ & $4.70 \pm 0.7$ & $5.66 \pm 0.7$ \\
\hline AEVD (100 mg/kg) & $37.66 \pm 3.4$ & $39.84 \pm 3.9$ & $284.33 \pm 6.1$ & $5.66 \pm 0.7$ & $5.01 \pm 0.6$ \\
\hline AEVD (200 mg/kg) & $32.16 \pm 3.2$ & $35.67 \pm 2.3$ & $278.66 \pm 5.1^{\mathrm{a}}$ & $4.90 \pm 0.8$ & $5.33 \pm 0.5$ \\
\hline
\end{tabular}

Values are explicated in the form of mean \pm SEM. To analyze the statistical significance, Dunnett's t-test and one-way ANOVA were executed. (F-value indicates statistical significance at ${ }^{*} \mathrm{p}<0.05,{ }^{*} \mathrm{p}<0.01$. t-value stands for statistical significance at ${ }^{\mathrm{a}} \mathrm{p}<0.05,{ }^{\mathrm{b}} \mathrm{p}<0.01$, and ${ }^{\mathrm{c}} \mathrm{p}<0.001$, respectively, when compared to Group I). SEM: Standard error mean, ANOVA: Analysis of variance, MEVD: Methanolic extract of Vernonia divergens, AEVD: Aqueous extract of Vernonia divergens, AST: Aspartate aminotransferase, ALT: Alanine aminotransferase, ALP: Alkaline phosphatase

of the extract was achieved by an extraintestinal action. The two extracts at the dose level of $100 \mathrm{mg} / \mathrm{kg}$ showed a significant decrease $(\mathrm{p}<0.01)$ in blood glucose at $8 \mathrm{~h}$, while at the same time, the dose level $200 \mathrm{mg} / \mathrm{kg}$ showed more significant $(\mathrm{p}<0.001)$ when compared to solvent control. The test extracts showed a significant decrease $(\mathrm{p}<0.001)$ of blood glucose level starting from $4 \mathrm{~h}$ onward in the tested dose levels, while standard drug possesses the same rate of significance beginning from $2 \mathrm{~h}$ while compared with solvent control. The observed data results of the experiments suggested that both the MEVD and AEVD are able to maintain the hypoglycemic effect up to $21^{\text {st }}$ day and no behavioral changes are observed during the treatment periods.

This study further supports the antidiabetic effect of the test extracts whose effectiveness persists up to 21 days and the blood sugar level decreases gradually during the observed days, which presumed that the test extracts contain some antidiabetic active principle responsible for this effect. The hypoglycemic active principle acts by initiating the release of insulin from the pancreatic cell of hyperglycemic animal (sulfonylurea like effect) [19]. The proper mechanism of action is further supported by oral glucose tolerance test, in which glucose level reduces in the response of test extract. While insulin level concerned in comparison with standard drug, it was observed that there was an increased plasma insulin level and hence concluded the insulinotropic effect [11]. Therefore, it is credible that glucose-lowering properties of the extracts strive a direct effect in hyperglycemic rat probably by a similar mechanism to insulin which was substantiated by an extrapancreatic mode of action. The experiment revealed that M.E. and A.E. of $V$. divergens $(200 \mathrm{mg} / \mathrm{kg})$ significantly $(\mathrm{p}<0.001)$ decrease the glucose level on hyperglycemic animal. The glucose lowering activity observed in the diabetic animal may be due to the stimulation of $\beta$-cells in the pancreatic islets.

It has been reported that diabetes is a heterogeneous metabolic disorder, in which one of the symptomatic characters is loss in body weight [20]. It has been stated that DM results deficiency to glucose utilization for energy leads to increased utilization \& decreased storage of proteins. By the above-stated reason, depletion of protein takes place resulting in reduced body weight [21]. The results of the study presented that the decreased loss of body weight might be contributed by increased use of glucose by the tissue.

The glycogen content of the liver and kidney of DM animals treated with M.E and A.E of leaves of $V$. divergens and standard drug was significantly increased when compared with solvent control after the completion of 21 days of treatment, even the test extracts and standard drug approach the content of glycogen toward normal glycogen level. It was reported that hyperglycemia results in decreased glucose utilization and glycogen synthesis [22]. The glycogen content in the liver and kidney increases in the extract-treated group compared to the diabetic rats indicating participation of the extract components in glycogen synthesis similar to insulin [23]. Dyslipidemia is a known complication associated with diabetes [24]. The abnormally high concentration of serum TG, TC, LDL, and low HDL observed in diabetic rats compared to control rats is in consonant with reports from previous studies [24-27], indicating that an increase in glucose level on induction of diabetes results in an equivalent rise in blood lipids. It has been reported that, in the diabetic patients those are untreated or under treatment, hypertriglyceridemia and hypercholesterolemia often occur due to the increased generation of VLDL and deficiency of lipoprotein lipase [28]. The result revealed that the test extract reduces VLDL, TC and TG actively. Hence, it might be surmised that, similar to insulin, the test extract is the prime cause for the endowment of the transcription of lipoprotein lipase.

The result of hematological parameters evidenced that the test extracts have no significant effect on the same and is evident for the safely used at the MEVD and AEVD for a longer duration time. The experimental approach has been conducted for the test extracts to elicit tonic response over an exposure period of 21 days' alteration in the marker enzymes such as AST, ALT, and ALP. The data obtained from this study also indicated that the MEVD significantly decreased 
the levels of AST, ALT, and ALP. The increased activity of transaminases, which are active in the absence of insulin due to increased availability of amino acids in diabetes, is believed to be responsible for the increased gluconeogenesis and ketogenesis observed in the disease [29]. Alanine and aspartate transaminase activities are used as an indicator of hepatocyte damage [30]. Elevation of serum ALP concentration in patients with DM has been observed for several years, but the source and reasons are unknown [31].

\section{CONCLUSION}

The findings of the current study indicated that MEVD and AEVD may get a place in the treatment of DM as hypoglycemic and/or antidiabetic agent. The MEVD and AEVD (DC.) Edgew. might be beneficial in effectively reducing the blood glucose concentration and managing of various complications of diabetes. However, in comparison between both the extracts, the M.E. was found to be significantly more potent than that of the A.E. in all aspects. Clinical studies are required to establish whether the administration of MEVD and AEVD can potentiate the antidiabetic effect of conventional agents.

\section{ACKNOWLEDGMENT}

The authors are contented to the Department of Pharmacology of School of Pharmaceutical Sciences, Siksha 'O' Anusandhan Deemed to be University for rendering adequate facility in the laboratory for the purpose of this research, and also to Dr. Manoj Ranjan Nayak for his kind support and cooperation.

\section{AUTHORS' CONTRIBUTION}

Laxmidhar Maharana: Design of protocol of the study, Manoj Kumar Sethi: Preparation and correction of the manuscript. Rudra Narayan Dash: Performance of whole experiments, Snigdha Pattnaik: Supervision of experiments.

\section{REFERENCES}

1. Alberti KG, Zimmet PZ. Definition, diagnosis and classification of diabetes mellitus and its complications. Part 1: Diagnosis and classification of diabetes mellitus provisional report of a WHO consultation. Diabet Med 1998;15:539-53.

2. Cline GW, Petersen KF, Krssak M, Shen J, Hundal RS, Trajanoski Z, et al. Impaired glucose transport as a cause of decreased insulin-stimulated muscle glycogen synthesis in Type 2 diabetes. $\mathrm{N}$ Engl J Med 1999;341:240-6.

3. King H, Aubert RE, Herman WH. Global burden of diabetes, 19952025: Prevalence, numerical estimates, and projections. Diabetes Care 1998;21:1414-31.

4. Boyle JP, Honeycutt AA, Narayan KM, Hoerger TJ, Geiss LS, Chen $\mathrm{H}$, et al. Projection of diabetes burden through 2050: Impact of changing demography and disease prevalence in the U.S. Diabetes Care 2001;24:1936-40.

5. Shukia R, Sharma SB, Puri D, Prabhu KM, Murthy PS. Medicinal plants for treatment of diabetes mellitus. Indian J Clin Biochem 2000;15 Suppl 1:169-77.

6. Odeigah PG, Taiwo IA, Akomolafe EO, Durojaiye DO. Hypoglycaemic actions of medicinal plants with tolbutamide in the albino rat. Diabetes Int 1999;9:71-3.

7. Taiwo IA, Odeigah PG, Ogunkanmi LA. The glycemic effects of Vernonia amygdalina and $V$. tenoreana with tolbutamide in rats and the implications for the treatment of diabetes mellitus. J Sci Res Dev 2008; 11:122-30

8. Gyang SS, Nyam DD, Sokomba EN. Hypoglycaemic activity of
Vernonia amygdalina (chloroform extract) in normoglycaemic and alloxan-induced hyperglycaemic rats. J Pharm Bioresour 2004;1:61-6.

9. Al-Ahmed FA, Dl-Densary ES, Zaki M, El-Sawaf HA, Abu-Jayyab AR Ineraction between diazekpamand oral antidiabetic agents on serum glucose. Insulin and chromium levels in rats. Biosci Rep 1989;9:347-50.

10. Dash GK, Suresh P, Ganapati S. Studies on hypoglycaemic and wound healing activities of Lantana camara Linn. J Nat Rem 2001;1:105.

11. Rath D, Panigrahy S, Panigrahi S, Kar D, Maharana L. Antidiabetic effect of extracts of Blumea lacera dc. In streptozotocin induced hyperglycemic rats. Int J Pharm Pharm Sci 2017;9:218-23.

12. Saxena AM, Murthy PS, Mukherjee SK. Mode of action of three structurally different hypoglycemic agents: A comparative study. Indian J Exp Biol 1996;34:351-5.

13. Maharana L, Kar DM, Pattnaik S. Antidiabetic evaluation of aqueous extract of aerial parts of Mollugo pentaphylla L. Int J Pharm Pharm Sci 2012;4:269-75.

14. Ghosh MN, editor. Fundamentals of Experimental Pharmacology. $2^{\text {nd }}$ ed. Calcutta: Scientific Book Agency; 1984.

15. Riley H, Spinks A. Biological assessment of tranquilisers. J Pharmacol 1958;10:657-71.

16. Kuikarni SK. Handbook of Experimental Pharmacology. $2^{\text {nd }}$ ed. New Delhi: Vallabh Prakashan; 1993

17. Fartyal M. Nerium oleander Linn. In vitro alpha amylase inhibitory potential of stem and root extracts. Int J Curr Pharm Res 2016;9:37-41.

18. Raphael KR, Sabu MC, Kuttan R. Hypoglycemic effect of methanol extract of Phyllanthus amarus Schum and Thonn on alloxan induced diabetes mellitus in rats and its relation with antioxidant potential. Indian J Exp Biol 2002;40:905-9.

19. Ng KW, Salhimi SM, Majid AM, Chan KL. Anti-angiogenic and cytotoxicity studies of some medicinal plants. Planta Med 2010; 76:935-40.

20. Available from: http://www.diabetes India.com

21. Guyton AC, Hall JE. Text Book of Medical Physiology. $11^{\text {th }}$ ed. Philadelphia, PA: Elsevier; 2005.

22. Akhtr MS, Khan QM, Khaliq T. Effect of Euphorbia prostrata and Fumaria parviflora in normoglycemic and alloxan treated hyperglycaemic rabbits. Planta Med 1984;50:138-42.

23. Davis SN, Granner DK. Insulin, oral hypoglycemic agents and the pharmacology of the endocrine pancreas. In: Goodman Gilman's the Pharmacological Basis of Therapeutics. $10^{\text {th }}$ ed. USA: The McGrawHill Companies Inc.; 2001.

24. Ayinla MT, Dada SO, Shittu ST, Olayaki LA, Akiode AO, Ojulari SL. Anti-hyperlipidemic effect of aqueous leaf extract of Ocimum gratissimum in alloxan induced diabetic rats. Int J Med Med Sci 2011;3:360-3

25. Soliman AM. Potential impact of Paracentrotus lividus extract on diabetic rat models induced by high fat/streptozotocin. J Basic Appl Zool 2016;77:8-20.

26. Elberry AA, Harraz FM, Ghareib SA, Gabr SA, Nagy AA, AbdelSattar E. Methanolic extract of Marrubium vulgare ameloriates hyperglycemia in streptozotocin-induced diabetic rats. Int J Diabetes Mellitus 2015;3:37-44.

27. Abdulazeez MA, Ibrahim K, Bulus K, Babvoshia HB, Abdullahi Y. Effect of combined use of Ocimum gratissimum and Vernonia amygdalina extract on the activity of angiotensin converting enzyme, hypolipidemic and antioxidant parameters in streptozotocin-induced diabetic rats. Afr J Biochem Res 2013;7:165-73.

28. Haardman JG, Limbird LE, Gilman AG. The Pharmacological Basis of Therapeutics. $10^{\text {th }}$ ed. New York: McGraw Hill; 2001.

29. Felig P, Marliss E, Ohman JL, Cahill CF Jr. Plasma amino acid levels in diabetic ketoacidosis. Diabetes 1970;19:727-8.

30. Whitehead MW, Hawkes ND, Hainsworth I, Kingham JG. A prospective study of the causes of notably raised aspartate aminotransferase of liver origin. Gut 1999;45:129-33.

31. Maxwell DB, Fisher EA, Ross-Clunis HA, Estep HL. Serum alkaline phosphatase in diabetes mellitus. J Am Coll Nutr 1986;5:55-9. 